\title{
'I didn't know what strong was until it was required': factors that promote retention among homeless students in higher education
}

\author{
Patrick Mulrenan, Julia Atkins and Simon Cox \\ Journal of Further and Higher Education, volume 44, number 2 (pages 273-284) \\ https://doi.org/10.1080/0309877X.2018.1533929
}

\begin{abstract}
This study examines the experience of homeless university students. A focus group and in-depth interviews were conducted among 16 homeless students at a university in London to determine the factors that enable them to remain at university despite being homeless. Homelessness has been increasing in the UK since 2010, particularly in London. Combined with the widening participation initiative, which encourages access to Higher Education for more disadvantaged communities, this means that increasing numbers of students may face homelessness during their studies. The study demonstrates considerable personal resilience among homeless students. These students find it hard to fully engage with other students, or with the wider university experience. Most were in fact too embarrassed to tell their university friends that they were homeless. Key factors that promoted resilience were sense of purpose, personal determination, and the relationship with their families. The critical relationship was, however, with their children. Decisions to attend and remain at university were based not on having a role model, but on the desire to provide a positive role model to their children. The study also acknowledges wider structural factors; homelessness is influenced by national and international trends outside the influence of individual and institutional actors.
\end{abstract}

KEYWORDS: Higher education, homelessness, students, widening participation, resilience

\section{Introduction}

This paper reports a small-scale explorative research project carried out with homeless students at a London university in 2016. The research examined the reasons why these students remain at university in the face of considerable personal challenges.

This research builds on current research in two ways. The first is that it reflects the experience of students at a 'post-1992' UK university. These universities were granted university status after 1992, and they tend to attract students who are mature, more local, and who also tend to be more socially disadvantaged than students at other universities. For example, 30 per cent of students in post-1992 universities are from BAME (Black, Asian and Minority Ethnic) backgrounds, compared to 18 per cent for the more selective and research-focused universities in the 'Russell Group' (OFFA 2015).

Also, the research focuses on students who were homeless when they arrived at university, or became homeless during their studies. Homelessness reflects housing pressures, which vary across the UK, and London is not necessarily representative of the whole country in this respect. However, given that universities tend to be located in urban areas with high housing demand (and in fact contribute to increased demand on housing), the challenges faced by students in this study may be reflected at other universities in the 
UK and elsewhere. Previous research has examined the impact of homelessness on education, but the focus has been on the education of children rather than on mature Higher Education students (Shelter 2004).

With 16 participants involved in the research, caution should be exercised in generalising the results of this study to other universities. In addition, it addresses the experience of students who have remained at university, rather than those who have left. But the numbers of homeless students who put themselves forward to be interviewed indicate that this may be an area for further research.

\section{Policy context}

This paper argues that the experience of homelessness among university students is in part the result of two broad policy themes: widening participation to Higher Education and changes in the housing market.

Higher Education policy in the last 25 years in the UK has promoted an increase in the number of students attending university, and widening participation to groups who have not traditionally benefited from Higher Education (Harding 2011; HEFCE 2015). This is part of an international trend: around 60 per cent of young adults in the European Union will have experience of Higher Education in their lifetimes (Katsarova 2015; Universities UK 2017).

UK universities can claim some success at widening participation in Higher Education. For example, in the decade to 2016, there was a 72 per cent increase in the number of young students coming from the most disadvantaged areas, and the difference in application rates between the most advantaged and most disadvantaged areas fell (BIS 2016a).

However, overall increases in participation in Higher Education have masked a number of key changes in student recruitment. In the decade to 2016, there was a decline in acceptances of both part-time and mature students (Universities UK 2017). People from Black and Minority Ethnic (BAME) backgrounds are now more likely than White people to attend university, with relatively high levels of participation among Indian and Chinese communities, and among those from BAME backgrounds in London with English as an additional language (BIS 2016a).

Differences in student background continue to have a significant impact on levels of participation, experience of university, and outcomes. People from the highest socioeconomic background are three times as likely to go to university, and nearly seven times as likely to go to 'selective' universities as those from the lowest quintile (BIS 2016a; University of Exeter 2018). These trends are most evident in the post-1992 universities that are the focus of this research. For example, 61.1 per cent of students at London Metropolitan University are from BAME communities (compared to 21.5 per cent in the UK HE sector), and 98.2 per cent are from state schools (compared to 89.9 per cent in the UK HE sector) (Office for Students 2018).

In addition, 'non-traditional' students face challenges in terms of remaining at university, gaining a 'good degree' (2:1 or above), and in subsequent career progression (RoseAdams 2013; Harding 2011). Taking into account factors such as choice of degree, those students from disadvantaged backgrounds, and from BAME backgrounds, are significantly less likely to get a 'good' degree (Universities UK 2017). BAME students are also more likely to express dissatisfaction with their degrees (Singh 2011), are less likely to be in 
employment six months after leaving university, and tend to earn less than their White counterparts (Zwysen and Longhi 2016).

Partly in response to these differences in outcomes, the focus of policymakers has shifted to a 'student lifecycle approach', of evaluating student experience through to employment (OFFA 2015). From 2018/19, UK universities will be assessed through the Teaching Excellence Framework (TEF), which includes metrics on satisfaction with teaching, support offered, retention, and the proportion of former students in employment. The Department for Business, Innovation and Skills (BIS) states that it will pay particular attention to outcomes for disadvantaged students (BIS 2016b).

Higher Education policy has therefore focused on groups that have been excluded from, or who do not fully benefit from, university study. In addition to those discussed already, these groups may include care leavers and disabled people (Thomas 2012; Moore, Sanders, and Higham 2013; Leatham and O'Connell 2010; BIS 2016a).

It is notable that these groups are also those that have been most adversely affected by changes in housing policy in the UK, and are therefore more likely to be homeless. Local authorities have traditionally provided relatively inexpensive and secure housing in the UK. However, the virtual cessation of new development since 1980, combined with sales of homes to existing tenants, has significantly reduced the number of local authority (or 'council') homes. At the same time, deregulation has expanded the number of privately rented homes. Private renting is associated with high costs, poor housing conditions, and insecurity of tenure (Barnes et al. 2013; DCLG 2015).

These changes have contributed to increased levels of homelessness in the UK. Homelessness can include those who are rough sleeping, staying with friends and relatives, and households who have been accepted as homeless by local authorities. Under current legislation, local authorities have a duty to provide secure housing for certain categories of household, for example, households who include dependent children or 'vulnerable' individuals. In practice, these households will be placed in 'temporary accommodation', and remain officially homeless until a suitable offer of accommodation can be made. Temporary accommodation may include bed-and-breakfast accommodation and hostels. However, the most common form of temporary accommodation is in the private rented sector; most students in this research were in this form of housing. As at December 2017, 78,930 households were in temporary accommodation in England, including 54,370 in London alone (MHCLG 2018). In addition, there are 69,000 'concealed' homeless households in London - that is, they are living within other households (Mayor of London, 2015) - and 7000 individuals sleeping on the streets of the capital. Shelter (2017) calculates that there are 307,000 homeless households in Britain.

Homelessness results from a complex interplay of structural and individual causes, and may take many forms. Particular groups are more at risk of homelessness. These groups include low-income households, people from BAME backgrounds, and people leaving care (DCLG 2017; Bramley and Fitzpatrick 2017). This paper argues that a policy of encouraging these groups into Higher Education will result in a higher proportion of students being homeless, and that these students face considerable barriers in achieving their academic potential.

\section{Methodology}


Participants were recruited through an email sent to students in two Schools in the university. The email asked if students were homeless, had been homeless, or were threatened with homelessness. Twenty-eight responses were received, 27 from the School of Social Professions. Around one in seven students at the university study in this School. Some of those who expressed an interest were unable to attend. Sixteen students participated in the research; 5 attended a focus group and 11 were interviewed. With the exception of one student, all the final participants were from the School of Social Professions, and were studying health, social work, youth work, or community work.

Ten of the participants were in temporary accommodation. This meant they had been accepted as homeless by the council and were placed in temporary accommodation in the private rented sector. Four had been homeless, and had since found private rented accommodation. One was staying with relatives while applying to the council for housing, and one was living in a hostel. None of those who were interviewed were in student accommodation. This reflected the profile of students at the university: more than 60 per cent are mature students and 73 per cent are local students (Office for Students 2018).

The profile of those who participated roughly reflected the demographics of the School of Social Professions, which has a relatively high proportion of mature, female students from BAME communities. Of those who self-identified, 3 were White, and 12 were Black African, Black Caribbean, or from Mixed heritage. Thirteen were women, 2 were men, and 12 had dependent children. There was a fairly even range of ages from 20 to 50 years old.

Interviews were carried out using a semi-structured approach and focused on the factors that enabled students to remain in their studies. This included student reflections on university support services and how these might be improved. The questions were kept broad and exploratory to encourage students to identify issues that were most important to them. However, prompts were used that reflected research on the challenges for nontraditional students in Higher Education, and the experience of households living in homeless temporary accommodation. The prompts were used to ensure that key areas were covered and to ensure that discussions were linked to the main research question. The interviews were taped and transcribed.

The interviews were followed by a focus group for other participants who were willing to discuss their situation with other students. The purpose of the focus group was twofold. It enabled participants to interact with one another and explore each other's experiences (Krueger and Casey 2009). The focus group also allowed the research team to explore and test some of the themes emerging from the interviews. The focus group lasted two hours, and was also taped and transcribed. This approach was designed to provide some flexibility in order to give insight into students' lived experience of homelessness and university. This flexibility proved to be helpful, as some unexpected issues emerged from the interaction of students with interviewers, and students with their peers in the focus group.

The process reflected the staged approach to thematic analysis identified by Braun and Clarke (2009). The team met several times during and after the interviews and focus groups to familiarise themselves with the transcripts. Inductive data-led analysis was then carried out to identify potential themes. As the interviews progressed, themes were modified, added, or deleted in response to additional data. This reflective and iterative process involved moving between the data, the themes, and the research question, and continued in response to commentary to the final research document. 
Themes were identified based partly on repeated patterns of response by students (Robson and MacCartan 2016). However, they also reflected the emotional resonance of issues for the participants. As noted already, the interviews involved emotional responses among the participants, particularly in relation to family relationships, and the team felt that these should be reflected in the findings. Some issues, such as religious faith, proved to be 'shooting stars', emerging unexpectedly but disappearing in subsequent interviews. Others, such as students' desire to be a role model to their children, were reflected very regularly among participants who had children.

There were some challenges in identifying the main themes of sense of purpose, personal resilience, family, and friendship. For example, the team had to return to the data multiple times to check that the themes were coherent and covered the full experience of the participants. There were also significant overlaps in the themes at the initial stage of the research, which reflected the complex interplay of personal, institutional, and structural factors that affected homeless students' lives. As the research progressed, some of the overlapping issues were resolved, but a strong inter-relationship remains between different themes.

There are limitations in this approach. Although the number of homeless students responding to the email may indicate that this is a significant problem, it is hard to gauge the extent of the issue in the university, or in other universities in the UK. Homelessness is higher in London than other parts of the country (DCLG 2017), and retention rates significantly lower (Social Market Foundation 2017). Also, the research process only addressed the experiences of those who had remained at university; many others in the same situation may have left. But the response to the research does indicate that this may be an area for future research.

Ethical approval was obtained through the university's Ethics Review Panel. Each participant was paid £25, reflecting the financial and time constraints they faced. The discussions involved personal issues, and proved to be an emotional experience for the participants. Many had not previously talked about their housing situation with staff or fellow students. The research was discussed with student support services in advance, and students were signposted to further support where required.

\section{Findings}

Unsurprisingly, the students discussed resilience in terms of personal struggle, rather than in terms of broader social structures. When asked about the factors that helped them stay at university, they identified a sense of purpose, personal resilience, family relationships, and friendship groups at the university.

\section{Sense of purpose}

The participants had a clear, measurable, and time-bound goal: to get a degree. To some extent, this meant they were not just trying to 'survive' challenges, but saw themselves as achieving a qualification that would improve their career prospects and help them escape homelessness:

I want it so bad. I just want to get through this and achieve something and get qualifications since the children were small. Things have always been in the way to stop 
me doing that, and I have always said that I'm not going to stop now. [female, 39 years old, with partner in temporary accommodation]

I can't stop and I so badly want to graduate and to be honest just leave this country (laughs). [female lone parent, 34 years old, 3 children, in temporary accommodation]

I was the first in my family to go to university, and this was a way to be different from my mum. I grew up in poverty and I wanted to get out of that. [female lone parent, 23 years old, 1 child, in private rented sector]

Previous research has indicated that students increasingly see their degree in terms of enhancing their employability (Cook et al. 2007; Leatham and O'Connell 2010; Elevation Networks Trust 2012). However, students' ambitions were not just to get a well-paid job. Participants in the focus group said they wanted to 'give back', and some of the interviewees were seeking a role where they could help others who are homeless:

I know what I am aiming for with a degree and now I am thinking about work in housing. My situation has pushed me this way. I want to make it better for others like me. [female, 39 years old, with partner in temporary accommodation]

I always wanted to do social work because I grew up in care. I've been passionate about it for many years and having a chance to do it is a dream for me. [female lone parent, 38 years old, 4 children, in temporary accommodation]

Coming to university will actually enhance my position [a job involving housing advice] and give me more knowledge on what I am doing. [female lone parent, 54 years old, 2 children, in temporary accommodation]

\section{Personal resilience}

For most of the homeless students, studying while homeless was just one of many problems they faced, including domestic violence, poor health, and financial problems. This reflects previous research on personal resilience, which indicates the challenges facing individuals are often not short term and discrete, but involve long-term and interlocking issues (Newman 2002).

The students saw their own personal determination as a key factor in remaining at university, while acknowledging that this came at considerable personal cost. One student, nicknamed 'the incredible survivor' by workmates, noted that:

They have this saying that God gives his battles to the hardest soldiers... I didn't know what strong was until it was required. [female lone parent, 34 years old, 3 children, in temporary accommodation]

Another called herself 'a woman on a mission', and added:

I wish the university could use me as an example... as someone who has been abused, lived here as an illegal migrant, back in university and is willing to go on to work with migrant workers that suffer from violence. [female lone parent, 1 child, 45 years old, in temporary accommodation] 
The students were proud that they had not let a series of negative events deter them from their studies. The participants in the focus group looked forward to the knowledge that they had 'done good' when they graduated, and interviewees noted:

I will do everything to finish this course. I am not going to give up. If it means sleeping in the street, I will sleep in the street in order to go to school. [female lone parent, 23 years old, 1 child, in private rented sector]

This can't hinder me any more, I'm in this situation. I've just got to like go through with it regardless... and I think I'm in control of it now where before it felt in control of me. [female lone parent, 34 years old, 3 children, in temporary accommodation]

However, the students' sense of pride was also something of a burden. Many were too embarrassed to talk to the university or even their friends and family about what they were going through. They were keenly aware of the impact of homelessness on their children, and wanted not to worry them. One student said, 'I get up in the night to cry. I can't let my daughter see me crying about being homeless' [female lone parent, 1 child, 45 years old, in temporary accommodation].

Even though they knew other students who had been homeless, they felt that they could not discuss it with their peers. One student explained that she felt personally 'reduced' [female lone parent, 23 years old, 1 child, in private rented sector] by her homeless situation and felt too ashamed to discuss it with her fellow students. For most of the participants, the research was an opportunity to discuss their homelessness for the first time, and for many it was an emotional experience. Almost all said they were too embarrassed to approach student services. Most in retrospect regretted this, and said they would advise others in their situation to tell the university about their homelessness.

\section{Family relationships}

The homeless students were clear that coming to, and staying at, university was not simply a matter of personal determination and resilience. They acknowledged that their decisions were strongly influenced by family relationships. They believed that their upbringing had helped them carry on, and wanted to repay their parents by graduating from the university. One noted that a key factor was 'my upbringing... because I have been brought up to realise that you don't just give up things and I am a very determined person' [female lone parent, 54 years old, 2 children, in temporary accommodation].

Other participants supported this view:

My Mum hasn't got a degree and I am a first-time student in the family. I just want to be different and give my children an example, make my Mum and them proud. [female lone parent, 38 years old, 4 children, in temporary accommodation]

[My parents] are very proud particularly being at a British university. You also don't want to let them down. You want them to come to graduation to take pictures. [female with partner, 35 years old, 1 child, staying with relatives]

[I was the] first person to come to university in my family. Yeah no pressure (laughs)... A lot of my aunts and uncles, their children haven't gone to university... I was the first to leave the country to go to university... a lot of the aunties were like 'she won't last'... three years later I'm still here. ...this definitely [influenced me to stay]. My mum can boast about this to others. [female, 27 years old, no children, privately renting] 
[My father] feels proud to have a child who has a degree. He talks to other people a lot... 'my daughter is in England and studying a degree.' He does not even know what his daughter is going through. [female lone parent, 23 years old, 1 child, in private rented sector]

The perceived influence of upbringing in promoting personal resilience has been noted in previous research (e.g. Hickman 2017). The role of parents on the student journey is also well documented (e.g. Mountford-Zimdars et al. 2015; Social Market Foundation 2017). However, a key finding of this research is that students' own children play a critical role in their journeys. The students wanted to be a good role model to their children, and to make their children proud of them:

Because I was a teenage mum... I know that most teenage mums don't have anything, and I don't want to be one of them statistics. [female lone parent, 23 years old, 1 child, in private rented sector]

To me it is let down to tell your child you do not have anything. If you have something it also motivates your child to become someone. [focus group]

I've seen students who have dropped out and I think please I do not want that... I'm so determined as a person. I just look at my children and I just want them to be proud of me. I look forward to that day when they can come and see that I have actually achieved something... I'm destined for that, really I am. [female lone parent, 34 years old, 3 children, in temporary accommodation]

When I first told them I was going to uni we had lost the property. My daughter, you know, gathered some paint and pencils and everything and she like gave it to me and she wrote me a note and she said, 'Mummy l'm so proud of you that you are going to uni'... my son is always like, 'what are you going to do there?'... but one day he said, 'Mummy, I am really proud of you'. [female lone parent, 54 years old, 2 children, in temporary accommodation]

Two weeks ago, my daughter said to me, 'Mum I'm going to say something to you.' I said, 'What is it, do you want a fiver?' 'No', she said, 'Mum I'm really really proud of you.' It brought me to tears. [female lone parent, 1 child, 45 years old, in temporary accommodation]

Previous research has found that personal resilience is promoted by the presence of a figure of influence, supporting the individual and their aspirations (Kilminster 2015; Canavan 2008). This study found that the key relationship that promoted resilience for these students was with their children.

\section{Friendship groups}

Previous studies have indicated that the most significant factor in retention is a welldeveloped sense of being a student and belonging at the university (Moore, Sanders, and Higham 2013; Thomas 2012; Gail Thomas and Hanson 2014; Social Market Foundation 2017). When challenges do happen, the support of friends and peers at the university may be critical (Wilcox, Winn, and Fyvie-Gauld 2005; Thomas 2012).

This research indicated a more nuanced picture for mature homeless students. For one single student, her friendship network was vital: 
Yeah, they gave me the motivation, they said come and stay with me. It's nice having that back-up... even if they didn't come from London, you had someone to be lost with... I think my networking was very important and that's what made me stay. [female, 27 years old, single, no children, privately renting]

However, most of the students faced severe time constraints and had no time to socialise outside the teaching timetable. Some of this was associated with work and family responsibilities, but for many, homelessness had a significant impact on their ability to develop friendship groups. For example, one interviewee in temporary accommodation had been moved eight times since 2009 , on one occasion to a town more than 20 miles from London:

Social activities for now, that's a no-no. [female, 35 years old, with partner, 1 child, staying with relatives]

Many of the students were aware that other students at the university had experienced homelessness. However, most had still not felt able to discuss their homelessness with their fellow students:

This is not something I would talk to them about. You know, like sometimes you want to keep your things to yourself... if you tell people your house was repossessed, especially from the culture I am from they would be like 'well you know you cannot afford it why did you?'... they would not be sympathetic. [female lone parent, 54 years old, 2 children, in temporary accommodation]

I just feel that everyone has their own issues and I didn't want other students to look at me thinking I haven't got a home. [lone parent, 38 years old, 4 children, in temporary accommodation]

I didn't mention it to anyone... I just felt I did not want anyone to sympathise with me and I think that's where I went wrong. The whole of the first year I never saw any lecturer... even my friends. I kept it to myself. [lone parent, 23 years old, 1 child, in private rented sector]

But this is not to argue that friendship groups are unimportant. Although they had limited time to socialise, and they did not feel they could be open about their situation, they felt that the time they had on campus to interact with others socially was important to their sense of well-being:

I mean just socialising - takes your mind away from [being homeless], definitely. [female lone parent, 23 years old, 1 child, in private rented sector]

When I am at uni sometimes I tend to forget the stress I have for some few minutes.... Because coming to school right now to see my friends I will be happy, but then when I go home I think, 'Oh God, I have to go back home again.' [female, 35 years old, with partner, 1 child, staying with relatives]

It makes it easier because when I come up here in the mornings on the train and you enter inside [name of university] you feel so much different, the pressure is gone, you feel like you are accomplishing something... the moment that you leave the pressure starts.

[female lone parent, 1 child, 45 years old, in temporary accommodation]

\section{Discussion}


This research provides insights into the practical challenges of widening participation in Higher Education. One such challenge for the students involved is homelessness. This often involves a series of negative events, but is also a process that reflects the wider housing market and economic context. However, by virtue of being at university, the focus of the participants is on the future. Most regarded obtaining a degree as a way to obtain well-paid employment, and to thereby solve their housing problems and perhaps help others in their situation.

Despite more than 25 years of policies that promote widening participation, policies and research sometimes fail to reflect the lived experience of mature students with families who come to university. For some young, single students, renting privately might be regarded as a 'rite of passage'. Sharing poor-quality accommodation may be seen as a temporary life experience, and they may have parents to fall back on if things get too tough. Participants in this research did not have this comfort. Their permanent home is in the private sector, and for most their housing situation is made all the more precarious by being in homeless temporary accommodation in this sector.

Previous research has suggested that 'non-traditional' students face a range of barriers to remaining at university, and to achieving their full educational potential. These include the attitude of their families and communities, preparedness for study, social integration, working during term time, and caring responsibilities (Cook et al. 2007; Gazeley and Aynsley 2012; Moore, Sanders, and Higham 2013; Thomas 2012). Homelessness could be regarded as just one more barrier to academic achievement. However, this exploratory research indicates that there are a number of features of homelessness among students that make it worthy of examining in its own right.

One factor that enabled students to maintain their studies was a sense of purpose. The short-term motivation was to get the best degree they could, and there was a strong sense from the interviews that students could picture themselves getting their degree award. One student said, 'I look forward to that day when they [her children] can come and see that I have actually achieved something... I'm destined for that, I really am' [lone parent, 34 years old, 3 children, in temporary accommodation].

Employment has previously been identified as a strong motivation for students in decisions to come to, and to stay at, university (Cook et al. 2007; Leatham and O'Connell 2010; Elevation Networks Trust 2012). Participants in this research were strongly aspirational, but their employment aspirations were guided by their own experience of homelessness, and the desire to use this to help others in a similar situation.

The sense of purpose outlined here was strongly linked to students' relationships with their children. Previous research has suggested that students' relationships with their families are instrumental in understanding recruitment and retention (e.g. Moore, Sanders, and Higham 2013). Widening participation to mature students means that the number of students with children may increase. The role of children in student decision making has yet to be fully addressed in research, and came out as a key theme of the interviews and focus groups. Many participants had not told their parents about their housing situation. However, this could not be hidden from their children. Many of the interviewees expressed guilt at not being able to provide adequate housing for their children.

Feelings of shame among homeless people are well documented (e.g. Crisis 2017) and partly explain why they do not access the services that they need. Less well documented is a sense of pride at overcoming barriers, and how the views of children inform decisions to participate in Higher Education. Both came out strongly in the interviews and focus 
groups. It is not just having a role model but being a role model that informed student views of their education. For most of the participants, a strong sense of pride and a desire to act as a role model for their children were critical in the way they thought about their studies, and in their determination to complete their degrees.

It is important to acknowledge the personal resilience of participants. Studies of nontraditional students are often grounded in the actions of individuals, and the role of their families and their communities. Research rightly celebrates the achievement of individuals 'bouncing back' from adversity (Bonnell et al. 2011; Harrow 2009; Masten 2001; Allan, McKenna, and Dominey 2014). However, it has been argued that focusing on individual resilience may ignore the structural context that surrounds them: 'at times, it seems as though we have lost sight of why people need to be resilient in the first place' (Davis 2014 , 5). What we need to focus on, according to Seccombe (2002), is 'changing the odds' rather than 'beating the odds'.

Although the participants in this research made a positive decision to go to university, they did not choose the wider context within which they made this decision. University funding has failed to increase in line with student numbers, and as graduates, they will leave the university with large debts. Combined with the extremely challenging London housing market, this means that they are undertaking their studies in a risky environment that is beyond their control.

\section{Conclusion}

The research raises some issues around policies of widening participation in Higher Education. The first issue is around how 'success' is measured. The Office for Fair Access defines positive outcomes in relation to access to university, academic success, and employability (OFFA 2015). However, it could be argued that even remaining at university represents a significant achievement for the students participating in this research project, given the challenges they face. Buzzanell $(\underline{2010}, 4)$ notes that even 'to be able to assert and perform the mundane in such trying times is a profound accomplishment'.

The second issue concerns the response of universities to their changing student profile. The students taking part in the research demonstrated a wide range of 'soft' skills such as resilience and adaptability. These are valued in a work and professional environment, and essential in completing their degrees. However, these skills command limited recognition within the academic element of their courses. This represents a challenge to universities to reflect on the extent to which learning and pedagogy are responding to the changing student body. As Roberts $(\underline{2011}, 189)$ notes, 'the changing expectations and needs of an increasingly diverse student population may have to be met through rethinking and widening practice.'

Some more specific recommendations for universities flow from this research. There is a limit to what universities can do in a housing market driven by policy at national and international levels; however, it is important to understand the extent of homelessness among university students. Universities in the UK are currently obliged to monitor care leavers coming to university. It would be helpful if the housing situation of students was monitored in the same way when they arrive at university and during their university careers.

One of the challenges of monitoring homelessness, and attempting to help homeless students, is that they may feel too embarrassed or ashamed to approach support services. 
Student services should have strategies to address housing and financial needs, but should also encourage homeless students to approach them for the help they need. But there is also a role for personal tutors, both in encouraging students to come forward and in providing the flexibility that homeless students might need in, for example, handing in assessments.

As well as providing individual support for homeless students, universities could promote resilience by building on the key assets that these students have. One of the key findings of this research is the critical role of students' children in encouraging them to come to university, and to stay at university. This relationship is a hitherto unacknowledged source of personal resilience for students, and could form the basis of a more positive, assetbased approach to promoting student success.

As noted already, there are limitations to this research. The sample is relatively small and drawn from one London university. It is also limited to those who have remained at university, despite the challenges of homelessness. It would be helpful to carry out further interviews with students who have left university without completing their degrees to assess the extent to which their housing situation influenced this decision.

\section{References}

1. Allan, J., J. McKenna, and S. Dominey. 2014. "Degrees of Resilience: Profiling Psychological Resilience and Prospective Achievement in University Inductees." British Journal of Guidance and Counselling 42 (1): 9-15. doi:10.1080/03069885.2013.793784. [Taylor \& Francis Online], [Web of Science ®], [Google Scholar]

2. Barnes, M., C. Cullinane, S. Scott, and H. Silvester. 2013. People Living in Bad Housing: Numbers and Health Impacts. London: NatCen Social Research. [Google Scholar]

3. BIS (Department for Business, Innovation and Skills). 2016a. Success as a Knowledge Economy. Teaching Excellence, Social Mobility and Student Choice. London: BIS. [Google Scholar]

4. BIS (Department for Business, Innovation and Skills). 2016b. Teaching Excellence Framework: Technical Consultation for Year Two. London: BIS. [Google Scholar]

5. Bonnell, J., P. Copestake, D. Kerr, R. Passy, P. Reed, R. Salter, S. Sarwar, and S. Sheikh. 2011. Teaching approaches that help build resilience to extremism among young people. London: Department for Education. [Google Scholar]

6. Bramley, G., and S. Fitzpatrick. 2017. "Homelessness in the UK: Who is Most at Risk?” Housing Studies. doi:10.1080/02673037.2017.1344957. [Taylor \& Francis Online], [Web of Science ®], [Google Scholar]

7. Braun,, V., and V. Clarke. 2009. "“Using Thematic Analysis in Psychology”." Qualitative Research in Psychology 3 (2): 77-101. doi:10.1191/1478088706qp063oa. [Taylor \& Francis Online], [Google Scholar]

8. Buzzanell, P. 2010. "Resilience: Talking, Resisting and Imagining New Normalcies into Being." Journal of Communication 6 (1): 1-14. doi:10.1111/j.14602466.2009.01469.x. [Crossref], [Google Scholar]

9. Canavan, J. 2008. "Resilience: Cautiously Welcoming a Contested Concept." Child Care in Practice 14 (1): 1-7. doi:10.1080/13575270701733633. [Taylor \& Francis Online], [Google Scholar]

10. Cook, R., M. Barkhaman, K. Audin, and M. Bradley. 2007. "How Social Class Differences Affect Students' Experience of university." Journal of Further and Higher Education 28 
(4): 407-421. doi:10.1080/0309877042000298894. [Taylor \& Francis Online], [Google Scholar]

11. Crisis. 2017. "I was all on my own": experiences of loneliness and isolation amongst homeless people. London: Crisis. [Google Scholar]

12. Davis, L. 2014. "Have We Gone Too Far with Resiliency?" Social Work Research 38 (1): 1-2. doi:10.1093/swr/svu003. [Crossref], [Web of Science B], [Google Scholar]

13. DCLG (Department for Communities and Local Government). 2017. Statutory Homelessness: January to March 2016 and homelessness prevention and relief: England. Accessed 15 June 2017. https://www.gov.uk/government/uploads/system/uploads/attachment data/file/53309 9/Statutory Homelessness and Prevention and Relief Statistical Release January to March 2016.pdf [Google Scholar]

14. DCLG (Department for Local Government and Communities). 2015. English House Condition Survey 2014 15: Private Rented Sector Report. London: DCLG. [Google Scholar]

15. Elevation Networks Trust. 2012. Race to the Top: the Experience of Black Students in Higher Education. London: Bow Group. [Google Scholar]

16. Gail Thomas, B., and J. Hanson. 2014. "Developing Social Integration to Enhance Student Retention and Success in Higher Education: the GROW@BU Initiative." Widening Participation and Lifelong Learning 16 (3): 58-70. doi:10.5456/WPLL.16.3.58. [Crossref], [Google Scholar]

17. Gazeley, L., and S. Aynsley. 2012. The contribution of pre-entry interventions to student retention and success. A literature synthesis of the Widening Access Student Retention and Success National Programmes Archive. York: Higher Education Academy. [Google Scholar]

18. Harding, J. 2011. "Financial Circumstances, Financial Difficulties and Academic Achievement Among First-Year Undergraduates." Journal of Further and Higher Education 35 (4): 483-499. doi:10.1080/0309877X.2011.584969. [Taylor \& Francis Online], [Google Scholar]

19. Harrow, J. 2009. Leadership and Resilience: Local Communities and Services in a Time of Fragmentation: Are there Reasons to be Cheerful? Edinburgh: Association of Chief Officers of Scottish Voluntary Organisations. [Google Scholar]

20. HEFCE (Higher Education Funding Council for England). 2015. 'Glossary' Accessed 12 November 2015. http://www.hefce.ac.uk/glossary/\#letterW [Google Scholar]

21. Hickman, P. 2017. "A Flawed Construct? Understanding and Unpicking the Concept of Resilience in the Context of Economic Hardship" Accessed 18 August 2017. https://0www.cambridge.org.emu.londonmet.ac.uk/core/services/aop-cambridgecore/content/view/6F4B08B9773246CF4B34076A7923845B/S1474746417000227a.pdf/fla wed construct understanding and unpicking the concept of resilience in the context of economic hardship.pdf. [Google Scholar]

22. Katsarova, I. 2015. Higher Education in the EU: Approaches Issues and Trends. EU: European Parliamentary Research Service. [Google Scholar]

23. Kilminster, H. 2015. "What an Interruption in Study can Reveal About Learner Motivation and resilience"

Accessed 18 March 2016. https://journals.beds.ac.uk/ojs/index.php/jpd/article/view/231/36 0. [Google Scholar]

24. Krueger, R., and A. Casey. 2009. Focus Groups: a Practical Guide for Applied Social Sciences. Thousand Oaks, CA: Sage. [Google Scholar]

25. Leatham, C., and P. O'Connell. 2010. "IIt's a Struggle': The Construction of the 'New Student' in Higher Education." Journal of Education Policy 18 (6): 597-615. [Google Scholar] 
26. Masten, A. 2001. "Ordinary Magic: Resilience Processes in Development." American Psychologist 56 (3): 227-238. [Crossref], [PubMed], [Web of Science ®], [Google Scholar]

27. Mayor of London. 2015. Housing in London 2015: The Evidence Base for The Mayor's Housing Strategy. London: Greater London Authority [Google Scholar]

28. MHCLG (Ministry for Housing, Communities and Local Government). 2018. 'Statutory Homelessness: January to March 2018 and Homelessness Prevention and Relief:

England'

Accessed 16 July 2018. https://www.gov.uk/government/uploads/system/uploads/attachm ent data/file/533099/Statutory Homelessness and Prevention and Relief Statistical Re lease January to March 2017.pdf [Google Scholar]

29. Moore, J., J. Sanders, and L. Higham. 2013. Literature Review of Research into Widening Participation to Higher Education. London: HEFCE. [Google Scholar]

30. Mountford-Zimdars, A., D. Zabri, J. Moore, M. Sanders, S. Jones, and L. Higham. 2015. Causes of Differences in Student

Outcomes. London: HEFCE. [Google Scholar]

31. Newman, T. 2002. Promoting Resilience: a Review of Effective Strategies for Child Care Services. Exeter: Centre for Evidence-Based Social Services. [Google Scholar]

32. OFFA (Office for Fair Access). 2015. National Strategy for Access and Student Success at Higher Education. London: BIS. [Google Scholar]

33. Office for Students. 2018. "Access and participation plans for London Metropolitan University" Accessed 16th July 2018. https://www.officeforstudents.org.uk/advice-andguidance/the-register/access-and-participation-plans/\#/AccessPlans/10004048 [Google Scholar]

34. Roberts, S. 2011. "Traditional practice for non-traditional students? Examining the role of pedagogy in Higher Education retention." Journal of Further and Higher Education 35 (2): 183-199. doi:10.1080/0309877X.2010.540320. [Taylor \& Francis Online], [Google Scholar]

35. Robson, C., and K. MacCartan. 2016. Real World Research. $4^{\text {th }}$ ed. Chichester: John Wiley and Sons Ltd. [Google Scholar]

36. Rose-Adams, J. 2013. "Leaving university early: exploring relationships between institution type and student withdrawal and implications for social mobility." Widening Participation and Lifelong Learning 15 (2): 96-112. doi:10.5456/WPLL.15.2.96. [Crossref], [Google Scholar]

37. Seccombe, K. 2002. "Beating the Odds' Versus 'Changing the Odds'”: Poverty, Resilience and Family Policy." Journal of Marriage and Family 64: 384-394. doi:10.1111/j.1741-

3737.2002.00384.x. [Crossref], [Web of Science B], [Google Scholar]

38. Shelter. 2004. Living in Limbo: Survey of Homeless Households Living in Temporary Accommodation. London: Shelter. [Google Scholar]

39. Shelter. 2017. Far From Alone: Homelessness in Britain in 2017. London: Shelter. [Google Scholar]

40. Singh, G. 2011. Black and Minority Ethnic (BME) Students' Participation in Higher Education: Improving Retention and Success. York: Higher Education Academy. [Google Scholar]

41. Social Market Foundation. 2017. On Course for Success? Student Retention at University. London: Social Market Foundation. [Google Scholar]

42. Thomas, L. 2012. Building Student Engagement and Belonging in Higher Education at a Time of Change: a Summary of Findings and Recommendations from the What Works? Student Retention and Success Programme. London: Paul Hamlyn Foundation. [Google Scholar]

43. Universities UK. 2017. Patterns and Trends in UK Higher Education. London: Universities UK. [Google Scholar] 
44. University of Exeter. 2018. Research into the Use of Contextual Data in Admissions. Exeter: University of Exeter: Centre for Social Mobility. [Google Scholar]

45. Wilcox, P., S. Winn, and M. Fyvie-Gauld. 2005. "It Was Nothing to do with the University, it was Just the People": the Role of Social Support in the First-Year Experience of Higher Education." Studies in Higher Education 30 (6): 707-722.

doi:10.1080/03075070500340036. [Taylor \& Francis Online], [Web of Science ®], [Google Scholar]

46. Zwysen, W., and S. Longhi. 2016. Labour Market Disadvantage of Ethnic Minority British Graduates: University Choice, Parental Background or Neighbourhood? London: Institute for Social and Economic Research. [Google Scholar]

\section{Additional information}

\section{Author information}

\section{Patrick Mulrenan}

Patrick Mulrenan is a Senior Lecturer in Housing at London Metropolitan University, and has previously worked at the Audit Commission.

\section{Julia Atkins}

Julia Atkins is an independent housing consultant. She has worked for regional government, including the London Research Centre and the Mayor and Greater London Authority

\section{Simon Cox}

Simon Cox is a Practice Excellence Advisor for Care and Support Services working with Genesis Housing Association.

\section{Funding}

This work was funded through a University Fellowship award. 